\title{
Idiopathic Pulmonary Vein Thrombosis - A presentation of two case reports and review of the current literature
}

\author{
Arpan Patel ${ }^{1}$, Sassine Ghanem ${ }^{2}$, Adaeze Nwosu-Iheme ${ }^{1}$ and Bradley Fletcher ${ }^{{ }^{*}}$ \\ ${ }^{*}$ Department of Hematology/Oncology, University of Florida, PO Box 100278, Gainesville Florida 32610 \\ ${ }^{2}$ Department of Internal Medicine, Staten Island University Hospital - Northwell Health, Staten Island, New York, 10305
}

Received: 21 November, 2017; Accepted: 19 December, 2017; Published: 28 December, 2017

*Corresponding author: Bradley Fletcher, Department of Hematology/Oncology, University of Florida, Gainesville FL 32610, Tel: 352-262-6237, Fax: 352-392-9696; E-mail: bsfletch@ufl.edu

\begin{abstract}
Pulmonary vein thrombosis (PVT) is a rare condition that has been associated with lobectomy and lung transplants. With increasing imaging technology, we are increasingly faced with the diagnosis and difficult treatment decisions for pulmonary vein thrombosis. Currently the clinical significance and treatment options are limited. Currently to our knowledge, only around ten individual cases of pulmonary vein thrombosis have been described. We review the cases and summarize demographics, comorbidities, clinical presentations, method of diagnosis, workup, treatment, and follow up. We also share our two cases and experiences with this condition. With the increased utilization of imaging, clinicians will identify PVT more frequently. Treatment should be considered if signs of dyspnea, hypoxia, and chest pain are present. Workup for thrombophilia should considered based on clinical history of thrombosis and the discretion of the clinician.
\end{abstract}

Keywords: Thrombosis; Pulmonary vein; Pulmonary hypertension; Anticoagulation

\section{Introduction}

Pulmonary vein thrombosis (PVT) is a condition that has been typically been associated with lobectomy and lung transplant. In one series, it has been speculated that the incidence of pulmonary vein thrombosis post lung transplantation in the early postoperative period (48 hours) is as high as 15\% [1]. Historically, nonsurgical pulmonary vein thromboses are known to be rare and a series of autopsies done on 100 lung cancer patients by Onuigbo and published in 1972 found 3 positive cases [1]. It was thereafter postulated that pulmonary vein thrombosis might be under diagnosed. Given current advances in imaging techniques and the availability of transesophageal echocardiogram, we are now more frequently faced with a diagnosis of PVT. The clinical significance and the optimal treatment modality of this entity is still unclear. The situation is further complicated if no underlying prothrombotic state or anatomic predisposing lesion is found. In this review, we will be presenting two cases of idiopathic pulmonary venous thrombosis followed by a review of the literature for reported cases to help better understand the most common presentations, clinical significances, and optimal management of idiopathic PVT.

\section{Case 1}

A 77-year-old female with a past medical history of carcinoid tumor of the gastrointestinal tract treated with resection, hypertension, dyslipidemia, hypothyroidism, lumbago, and restless legs syndrome presented to the emergency department with a chief complaint of acute shortness of breath. The patient stated that her shortness of breath developed while she was walking up to a tree stand during a hunting trip. This was preceded by a four-hour drive during which she had stopped intermittently and walked around. Shortness of breath was present at rest and worsened with exertion and with lying flat. She denied any leg swelling, leg pain, chest pain, fever, cough or chills. She had no previous personal or family history of thrombosis or clotting disorders. She was up to date with her age appropriate cancer screening with a normal mammogram and colonoscopy that had been done within the previous 6 months. She is also a nonsmoker and denies any history of alcohol or drug use. A computed tomography (CT) angiography of the chest was performed to rule outpulmonary embolism. The CT angiography did not show any evidence of thromboembolic disease to the level of the segmental arteries. It did reveal however a non-occlusive thrombus in the inferior right pulmonary vein. A cardiac echography showed normal left ventricular systolic function and no dilation of ventricles or increase in obvious cardiac pressures. In addition, the right ventricle free wall appeared mildly hypokinetic with relative preservation of contractility at the apex suggestive of McConnell's sign. The troponins, brain natriuretic peptide, and electrocardiogram were normal. Her coagulation profile including prothrombin time (PT), partial thromboplastin time (PTT), were normal on admission and her complete blood count (CBC) was within normal limits. Further workup revealed absence of Factor $\mathrm{V}$ Leiden mutation. Protein $\mathrm{C}$ and $\mathrm{S}$, despite being done during the initial diagnosis, were negative. A venous duplex ultrasound of the lower extremities revealed no signs of thrombosis. Due to her ongoing dyspnea, she was treated for an active thrombosis; the patient was started on a heparin intravenous infusion on admission and was discharged on rivaroxaban for a total of three months after improvement of her symptoms. Anticoagulation was discontinued thereafter and the patient has been followed 
up for approximately a year without any thrombosis issues or dyspnea thus far.

\section{Case 2}

A 75-year-old female with a past medical history of asthma, gastroesophageal reflux disorder, dyslipidemia, and migraines presented to the hematology clinic for management of pulmonary vein thrombosis. Two months prior shehad presented to her pulmonologist with a chief complaint of atypical chest pain that radiated bilaterally around her lower ribs. She described the pain as a pins and needles feeling. A CT scan with intravenous (IV) contrast was ordered on which showed no evidence of pulmonary emboli, but revealed a pulmonary vein thrombosis in the left lower lobe that was $1.0 \times 0.5 \mathrm{~cm}$ in size. She also had a 1.8 $\mathrm{x} 1.0 \mathrm{~cm}$ left aorticopulmonary lymph node. Due to this abnormal finding she was sent to the hospital, but no anticoagulant therapy was given. She was on aspirin previously, which was increased to aspirin $81 \mathrm{mg}$ PO BID. At the time of her presentation to the clinic, she reported feeling better with resolution of her chest pain over two months. She reported wheezing and shortness of breath with a history of uncontrolled asthma and frequent exacerbations over the past year. She had no history of coronary artery disease. Patient has no previous personal or family history of thrombosis or clotting disorders. She is also a non-smoker and denies any history of alcohol or drug use. Patient had a normal CBC, PT, and PTT. A D-dimer was performed in the clinic and this was negative. There was no plan to get repeat imaging of the chest. Workup for antiphospholipid syndrome, which could be an acquired cause of thrombophilia, was performed given her history of asthma and possible autoimmune disease. Anticardiolipin IgM and IgG and anti-Beta 2 glycoprotein IgM and IgG were negative and the Russell viper venom time was normal. No anticoagulation was started due to resolution of the patient's symptoms. The patient was eventually lost to follow-up.

\section{Discussion}

When treating any thrombosis one must consider the underlying etiology and attempt to treat the reason for its formation. This would help clarify the risk of recurrence and whether this thrombus is a manifestation of an underlying disease or is the primary problem by itself. To our knowledge after extensive literature review, only 10 cases of idiopathic PVT have been reported in the literature, please refer to table 1 [317]. We excluded all cases with an abnormal hypercoagulability workup including those with abnormal coagulation profiles (PTPTT), protein C deficiency, protein S deficiency, antithrombin III mutation, history of priorthrombosis, atrial fibrillation, and malignancy.

PVT has been described in the literature over many years. Wyatt et al.in 1953 experimented with ligation of pulmonary veins in canine subjects and studied the morphological and histological evolution [11]. The effect of acute pulmonary vein ligation showed diffuse capillary congestion and extravasation of blood into the lungs. Interestingly, within 6 weeks, anatomical study revealed clearance of blood constituents from the lung with complete expansion of the lung at 12 months. There was no evidence of infarction other than slight scarring. This was later corroborated by Hurwitz et al,who managed to demonstrate the expansion of bronchial venous collaterals, that helped decongest the lung and resolve the initial consolidation that resulted from venous ligation [11]. Another case involved a 47-year-old female who presented with massive hemoptysis [11]. The pathological finding of red hepatization (presence of red blood cells, neutrophils, and fibrin in the pulmonary alveolus/alveoli signifying congestion) of the lung and an air-space consolidation of the left lower lobe were consistent with the pathological findings in the canine subjects. The patient reported by Mumoli and Ceipresented with shortness of breath and had a consolidation on the CXR consistent with the thrombosis [5]. In addition, the patient reported by Selvidge and Gavanthad patchy opacities on chest x-ray consistent with the right lower lobe thrombosis yet had no pulmonary symptoms [3]. Seventy percent of idiopathic pulmonary venous thrombosis presented with chest pain and in five of those cases the chest $\mathrm{x}$-ray was normal (Table 1). One would argue, therefore, whether the finding of the pulmonary vein thrombosis in this case was incidental and that the lung had already adapted to the thrombosis and developed the appropriate venous collaterals to decongest the affected lobes. In a systematic review done by Vazquez et al, on nonsurgical patients with PVT not limited to the idiopathic cases, the most common presenting symptom was dyspnea in $13 / 26$ (50 \%) of the patients, followed by chest pain in $11 / 26$ (42.3\%), and hemoptysis in 6/26 (23\%) [11].In the first case, we presented all the workup had been negative and the shortness of breath was attributed to the pulmonary vein thrombosis through an elimination process. The second case we presented however was lost to follow up and it is unclear whether the chest pain was linked to her pulmonary vein thrombosis.

There is no gold standard for diagnosis of pulmonary vein thrombosis. Transesophageal echocardiography was used to detect PVT after lung transplantation by Schulman et al. [1]. Multiple detector computed tomography (MDCT) was shown to be an effective tool in detecting PVT as reported by Takeuchi [11]. In his study, he performed 64-slice MDCT on 57 consecutive elderly Japanese patients presenting with chest pain and found PVT in 35 (61\%) patients [11]. No thrombophilia testing was performed on these patients and the etiology of these PVTs is unclear.Other imaging options previously used to diagnose PVT is transthoracic echocardiogram, pulmonary angiogram, cardiac gated magnetic resonance imaging and pulmonary CT done with a pulmonary embolus protocol [3]. It is important to keep in mind that CT examinations that are meant to investigate arterial anatomy may be misleading. Pooropacification of the pulmonary veins because of rapid washout may cause a true filling defect to be overlooked. Mixing artifactsfrom opacified and un opacified blood in the atrium may falsely mimic a left atrial mass. A longer scan delay may reduce these artifactsand allow better evaluation of the pulmonary veins and the cardiac chambers [3].

The D-dimer level does not appear to be correlated with the presence of a PVT. In the five cases of idiopathic PVT where the D-dimer level was reported [7,8,10-12], the d-dimer level was normal in four of the five cases.In addition, in the study 


\begin{tabular}{|c|c|c|c|c|c|c|c|c|}
\hline $\begin{array}{l}\text { Author, } \\
\text { year }\end{array}$ & $\begin{array}{l}\text { Age, } \\
\text { Gender }\end{array}$ & Comorbidities & $\begin{array}{l}\text { Clinical } \\
\text { Presentation }\end{array}$ & $\begin{array}{l}\text { Initial } \\
\text { method of } \\
\text { diagnosis }\end{array}$ & Result & $\begin{array}{l}\text { Further Workup } \\
\text { done }\end{array}$ & Treatment & Follow up \\
\hline $\begin{array}{l}\text { 1Selvidge } \\
\text { and Gavant } \\
1999^{11}\end{array}$ & $\begin{array}{l}33 \text { yo } \\
\text { Female }\end{array}$ & $\begin{array}{l}\text { Sickle cell trait, } \\
\text { smoker, cocaine } \\
\text { user }\end{array}$ & $\begin{array}{l}\text { Acute onset } \\
\text { of left-sided } \\
\text { abdominal } \\
\text { pain with } \\
\text { nausea and } \\
\text { vomiting. }\end{array}$ & $\begin{array}{l}\text { Contrast } \\
\text { enhanced } \\
\text { abdominal } \\
\text { CT }\end{array}$ & $\begin{array}{l}\text { Irregular, small areas } \\
\text { of non-enhancing } \\
\text { infarction within } \\
\text { the spleen and a } \\
\text { 2-cm diameter filling } \\
\text { defect in the left } \\
\text { atrium extending } \\
\text { from a thrombus in } \\
\text { the distal right lower } \\
\text { pulmonary vein. }\end{array}$ & $\begin{array}{l}\text { CXR showed patchy } \\
\text { opacities in the right } \\
\text { lower lobe. } \\
\text { TTE: Normal findings } \\
\text { but pulmonary veins } \\
\text { not well visualized, } \\
\text { refused TEE. } \\
\text { ECG gated MRI: } \\
\text { bland } \\
\text { thrombosis of } \\
\text { the right lower } \\
\text { pulmonary vein } \\
\text { with extension into } \\
\text { the left atrium. }\end{array}$ & $\begin{array}{l}\text { Oral } \\
\text { anticoagulant } \\
\text { therapy }\end{array}$ & $\begin{array}{l}\text { Repeat CT } \\
\text { examination } \\
\text { in } 2 \text { months } \\
\text { showed } \\
\text { marginal } \\
\text { decrease in } \\
\text { thrombus } \\
\text { size. }\end{array}$ \\
\hline $\begin{array}{l}\text { 2Alexander } \\
\text { et al. } 2009^{12}\end{array}$ & $\begin{array}{l}47 \text { yo } \\
\text { African } \\
\text { female }\end{array}$ & $\begin{array}{l}\text { No known } \\
\text { comorbidities. }\end{array}$ & $\begin{array}{l}\text { Massive } \\
\text { hemoptysis } \\
\text { associated } \\
\text { with left chest } \\
\text { pain and mild } \\
\text { dyspnea }\end{array}$ & $\begin{array}{l}\text { On } \\
\text { pathology } \\
\text { after left } \\
\text { lower } \\
\text { lobectomy. }\end{array}$ & $\begin{array}{l}\text { Macroscopic cut- } \\
\text { sections of the } \\
\text { lung parenchyma } \\
\text { demonstrated red } \\
\text { hepatization with } \\
\text { thrombosis of the } \\
\text { pulmonary venous } \\
\text { system On histology } \\
\text { of the resected } \\
\text { lobe, features of a } \\
\text { recent hemorrhagic } \\
\text { infarction were seen. }\end{array}$ & $\begin{array}{l}\text { TTE: no evidence } \\
\text { of thrombus in left } \\
\text { atrium. }\end{array}$ & $\begin{array}{l}\text { Surgical } \\
\text { resection of } \\
\text { affected lobe and } \\
\text { thrombectomy }\end{array}$ & Unknown \\
\hline $\begin{array}{l}\text { 3Mumoli } \\
\text { and Cei } \\
2012^{13}\end{array}$ & $\begin{array}{l}80 \text { yo } \\
\text { male }\end{array}$ & $\begin{array}{l}\text { Coronary } \\
\text { artery disease, } \\
\text { CABG s/p MI, } \\
\text { Congestive } \\
\text { Heart Failure }\end{array}$ & $\begin{array}{l}\text { Acute } \\
\text { shortness of } \\
\text { breath }\end{array}$ & CT Chest & $\begin{array}{l}\text { Bilateral pleural } \\
\text { effusions and a } \\
\text { large thrombus in } \\
\text { the left superior } \\
\text { pulmonaryvein }\end{array}$ & $\begin{array}{l}\text { CXR: near-round } \\
\text { opacity in the } \\
\text { upperleft lobe with } \\
\text { fissure involvement } \\
\text { TTE: Ejection } \\
\text { Fraction: } 30 \% \\
\text { Patient refused TEE. } \\
\text { Hypercoagulable } \\
\text { workup } \\
\text { normal except } \\
\text { Homocysteine:18.5 } \\
\text { Hmol/L }\end{array}$ & $\begin{array}{l}\text { Enoxaparin } \\
\text { then bridged to } \\
\text { Warfarin. }\end{array}$ & $\begin{array}{l}\text { Resolution } \\
\text { of thrombus } \\
\text { on Chest } \\
\text { CT after } 3 \\
\text { months. }\end{array}$ \\
\hline $\begin{array}{l}\text { 4Takeuchi } \\
2012^{14}\end{array}$ & $\begin{array}{l}79 \text { yo } \\
\text { male }\end{array}$ & Hypertension & Chest pain & $\begin{array}{l}64 \text {-MDCT } \\
\text { to evaluate } \\
\text { coronary } \\
\text { artery } \\
\text { anatomy }\end{array}$ & $\begin{array}{l}17.2 \times 1.2 \times 1.3 \mathrm{~mm} \\
\text { thrombus was } \\
\text { situated at the } \\
\text { proximal side } \\
\text { of left upper } \\
\text { pulmonary vein and } \\
\text { calcification of left } \\
\text { anteriordescendant } \\
\text { artery }\end{array}$ & & Warfarin & Unknown \\
\hline
\end{tabular}




\begin{tabular}{|c|c|c|c|c|c|c|c|c|}
\hline $\begin{array}{l}\text { Wu et al. } \\
2012^{5}\end{array}$ & $\begin{array}{l}30 \text { yo } \\
\text { male }\end{array}$ & Hypertension & Chest pain & $\begin{array}{l}\text { CT } \\
\text { Chest, PE } \\
\text { protocole }\end{array}$ & $\begin{array}{l}\text { Multifocal } \\
\text { consolidation } \\
\text { and ground-glass } \\
\text { opacities in the } \\
\text { left lower lobe, } \\
\text { left-sided effusion, } \\
\text { well-defined filling } \\
\text { defect and occlusion } \\
\text { within a left inferior } \\
\text { pulmonary vein, and } \\
\text { homogeneous hypo- } \\
\text { dense attenuation } \\
\text { in the left atrium } \\
\text { after contrast } \\
\text { administration }\end{array}$ & $\begin{array}{l}\text { D-Dimer: normal } \\
\text { Thrombophilia } \\
\text { screen (anti } \\
\text { thrombin III level, } \\
\text { protein C level, } \\
\text { and protein S } \\
\text { level) and tumor } \\
\text { markers (including } \\
\text { Carcino-embryonic } \\
\text { Antigen, Alpha } \\
\text { Fetoprotein, CA19- } \\
\text { 9, Carbohydrate } \\
\text { Antigen-125, and } \\
\text { Neuronspecific } \\
\text { Enolase) were } \\
\text { normal TTE: 2-cm } \\
\text { diameter filling } \\
\text { defects in the left } \\
\text { atrium suggestive of } \\
\text { thrombus. }\end{array}$ & $\begin{array}{l}\text { Left atrium } \\
\text { mass resection } \\
\text { and a left lower } \\
\text { lobectomy. } \\
\text { Pathology } \\
\text { showed } \\
\text { thrombus in } \\
\text { pulmonary vein } \\
\text { and left atrium. } \\
\text { Patient was then } \\
\text { started on oral } \\
\text { anticoagulation. }\end{array}$ & Unknown \\
\hline $\begin{array}{l}\text { 5Takeuchi } \\
2013^{15}\end{array}$ & $\begin{array}{l}73 \text { yo } \\
\text { male }\end{array}$ & $\begin{array}{l}\text { Dyslipidemia, } \\
\text { asthma }\end{array}$ & $\begin{array}{l}\text { Chest pain } \\
\text { once a month }\end{array}$ & $\begin{array}{l}\text { 64-MDCT } \\
\text { to evaluate } \\
\text { coronary } \\
\text { artery } \\
\text { anatomy }\end{array}$ & $\begin{array}{l}\text { No coronary artery } \\
\text { stenosis. Thrombus } \\
\text { in the left upper } \\
\text { pulmonary vein }\end{array}$ & $\begin{array}{l}\text { CXR: Normal. } \\
\text { D-dimer: }<0.5 \mu \mathrm{g} / \mathrm{mL} \\
\text { Protein S activity: } \\
96 \% \text { Protein C } \\
\text { activity : } 131 \%\end{array}$ & $\begin{array}{l}\text { Dabigatran } \\
\text { 150mg q12h }\end{array}$ & $\begin{array}{l}\text { Resolution } \\
\text { of thrombus } \\
\text { on repeat } \\
\text { CT after } 3 \\
\text { months. }\end{array}$ \\
\hline $\begin{array}{l}\text { 6Takeuchi, } \\
2013^{16}\end{array}$ & $\begin{array}{l}70 \text { yo } \\
\text { male }\end{array}$ & $\begin{array}{l}\text { Coronary artery } \\
\text { disease }\end{array}$ & Chest pain & $\begin{array}{l}64 \text {-MDCT } \\
\text { to evaluate } \\
\text { coronary } \\
\text { artery } \\
\text { anatomy }\end{array}$ & $\begin{array}{l}\text { Large thrombi in left } \\
\text { lower pulmonary } \\
\text { vein expanding into } \\
\text { the left atrium. }\end{array}$ & $\begin{array}{l}\text { CXR: normal TTE: } \\
\text { Thrombus in the left } \\
\text { atrium } 30.2 \mathrm{mmx} 8.1 \\
\text { mm, no thrombus in } \\
\text { left atrial appendage }\end{array}$ & Aspirin $100 \mathrm{mg}$ & Unknown \\
\hline $\begin{array}{l}\text { 7Takeuchi } \\
2014^{17}\end{array}$ & $\begin{array}{l}68 \text { yo } \\
\text { male }\end{array}$ & $\begin{array}{l}\text { Hypertension, } \\
\text { Dyslipidemia, } \\
\text { Previous stroke }\end{array}$ & Chest pain & $\begin{array}{l}64 \text {-MDCT } \\
\text { to evaluate } \\
\text { coronary } \\
\text { artery } \\
\text { anatomy }\end{array}$ & $\begin{array}{l}\text { Calcification of the } \\
\text { coronary arteries. } \\
\text { A thrombus in } \\
\text { the right lower } \\
\text { pulmonary vein. }\end{array}$ & $\begin{array}{l}\text { CXR: NormalD- } \\
\text { dimer: } 0.5 \mu \mathrm{g} / \mathrm{mL} \\
\text { Protein } S \text { activity: } \\
66 \% \\
\text { Protein C activity } \\
: 155 \%\end{array}$ & Dabigatran & $\begin{array}{l}\text { Partial } \\
\text { resolution } \\
\text { of thrombus } \\
\text { on repeat } \\
\text { CT after } 3 \\
\text { months. } \\
\text { Patient no } \\
\text { longer had } \\
\text { chest pain } \\
\text { while on } \\
\text { Dabigatran. }\end{array}$ \\
\hline $\begin{array}{l}\text { 8Takeuchi, } \\
2015^{18}\end{array}$ & $\begin{array}{l}82 \text { yo } \\
\text { male }\end{array}$ & $\begin{array}{l}\text { Hypertension, } \\
\text { Dyslipidemia }\end{array}$ & Chest pain & $\begin{array}{l}\text { 64-MDCT } \\
\text { to evaluate } \\
\text { coronary } \\
\text { artery } \\
\text { anatomy }\end{array}$ & $\begin{array}{l}\text { Thrombus in } \\
\text { the right lower } \\
\text { pulmonary vein }\end{array}$ & $\begin{array}{l}\text { D-dimer: } 0.5 \mu \mathrm{g} / \mathrm{ml} \\
\text { Protein S activity: } \\
85 \% \text { Protein C } \\
\text { activity : } 107 \%\end{array}$ & Dabigatran & $\begin{array}{l}\text { Thrombus } \\
\text { became } \\
\text { vague, fine } \\
\text { and clear } \\
\text { on repeat } \\
\text { CT after } 3 \\
\text { months }\end{array}$ \\
\hline
\end{tabular}




\begin{tabular}{|c|c|c|c|c|c|c|c|c|}
\hline $\begin{array}{l}\text { Rana et al. } \\
2016^{10}\end{array}$ & $\begin{array}{l}63 \text { yo } \\
\text { male }\end{array}$ & $\begin{array}{l}\text { No past medical } \\
\text { history }\end{array}$ & $\begin{array}{l}\text { One week } \\
\text { history of } \\
\text { chest pain }\end{array}$ & $\begin{array}{l}\text { CT } \\
\text { pulmonary } \\
\text { angiogram }\end{array}$ & $\begin{array}{l}\text { No pulmonary } \\
\text { embolism nor any } \\
\text { other lung pathology } \\
\text { Thrombus in the } \\
\text { pulmonary vein, } \\
\text { extending into the } \\
\text { leftatrium. }\end{array}$ & $\begin{array}{l}\text { D-dimer: } 1800 \mathrm{ng} / \\
\text { mL CXR: normal TTE } \\
\text { and TEE confirmed } \\
\text { pulmonary vein } \\
\text { thrombosis } \\
\text { Pulmonary } \\
\text { artery systolic } \\
\text { pressure: } 28 \mathrm{~mm} \\
\text { Hg Thrombophilia } \\
\text { screen, antinuclear } \\
\text { antibodies, and } \\
\text { tumour markers } \\
\text { (alpha fetoprotein, } \\
\text { beta } 2 \text { microglobulin, } \\
\text { CA } 19-9 \text {, and PSA): } \\
\text { normalantibodies, } \\
\text { and tumour markers } \\
\text { (alpha fetoprotein, } \\
\text { beta } 2 \text { microglobulin, } \\
\text { CA } 19-9 \text {, and PSA): } \\
\text { normal }\end{array}$ & $\begin{array}{l}\text { Low molecular } \\
\text { weight heparin } \\
\text { then switched to } \\
\text { Warfarin }\end{array}$ & $\begin{array}{l}\text { Repeat CT } \\
\text { in } 6 \text { months } \\
\text { showed } \\
\text { resolution of } \\
\text { thrombus. }\end{array}$ \\
\hline
\end{tabular}

Abbreviations: CABG: Coronary artery bypass grafting, CT: computed tomography, CXR: Chest X-ray, MI: Myocardial infarction, MDCT: Multiple detector computed tomography, PE: Pulmonary embolus, TEE: Transesophageal echocardiography, TTE: Transthoracic echocardiogram, yo: year old

by Takeuchi, among the 23 patients with PVT whose D-dimer levels were examined,17 patients (74\%) had a normal value. Further studies with a larger population are required to validate the presence or absence of a correlation between PVT and the D-dimer level. This proves to be especially difficult since this should be done in patients with idiopathic PVT which is rarely the case since in the setting of malignancy or in the post-surgical setting, D-dimer levels are already elevated. In the second case we reported, D-dimer level was normal but this was two months after the diagnosis of the PVT and not in the acute setting.

The main concern regarding pulmonary vein thrombosis is whether a risk of thromboembolism exists. Grau et al. studied 18 cases of cryptogenic stroke to check for existence of PVT and did not find any PVT in any of the cases [11].They therefore concluded that there was a lack of evidence for PVT in cryptogenic stroke. The number of cases that they studied however, was extremely small and the quality of the magnetic resonance angiography images was good in only 14 of those cases. While systemic thromboembolism is very rare in PVT cases, it has been previously described in the literature. Among all previous reports of idiopathic PVT, only one case reported splenic infarctions that they had attributed to the PVT [3]. It is important to note however, that this case was further complicated by the patient having sickle cell trait which is very rarely associated with splenic infarctions. Renal infarction was reported in a patient who developed PVT post lobectomy, and an ischemic stroke was reported in a patient with PVT revealing metastatic choriocarcinoma and in a patient with PVT and paroxysmal atrial fibrillation not on any anticoagulation $[11,12,19]$. Whether the systemic embolus was directly linked to the PVT in these patients or whether it was linked to the underlying prothrombotic state of post-surgery, malignancy or atrial fibrillation presents a clinical dilemma. This also raises the question as to whether treatment is justified for newly diagnosed PVT.
To date there has been no randomized control trial comparing treatments in pulmonary vein thrombosis. In the previous cases reported, warfarin and dabigatran has been used with variable success (Table 1). The cases reported by Mumoli and Cei, and Rana et al,showed complete resolution of the thrombus with warfarin therapy [5,12]. Dabigatran was first used in this indication by Takeuchi who reported one case in 2013 that showed complete resolution of the PVT, whereas two other cases showed partial resolution after 3 months $[8,10,11]$.Furthermore, in his study on the prevalence of PVT in elderly patients with chest pain, Takeuchi treated 35 patients with anticoagulation of which only 2 were on warfarin and the rest were treated with dabigatran $[14,15,17]$. Of these patients, only one patient had a complete resolution of his thrombus after 3 months $[14,15,17]$. The patients however noticed a resolution of their shortness of breath and chest pain during and after treatment $[14,15,17]$. Alexander et al. treated their patient with lobectomy and had the thrombus surgically removed during the same procedure [4]. Treatment for PVT therefore is up to the physician's discretion until enough data in the literature exists to establish the superiority of one treatment modality.

\section{Conclusion}

With the progress of imaging and its wide utilization, clinicians are increasingly likely to be faced with the diagnosis of PVT. It is unclear, in a nonsurgical setting and in patients who exhibit dyspnea and chest pain, if the diagnosis of PVT explains the symptoms. However, there is anecdotal evidence that some patients did have resolution of symptoms after treatment with anticoagulation. Therefore, in clinical practice, a PVT should be considered an incidental finding and should not refrain the physician from completing his or her workup according to the initial presentation and symptoms. In the absence of sufficient data, it is up to the discretion of the hematologist as to whether a thrombophilia workup or anticoagulation treatment is required in the management of PVT found on imaging. 


\section{References}

1. S D Selvidge and M LGavant, "Idiopathic Pulmonary Vein Thrombosis: Detection by CT and MR Imaging.," AJR Am J Roentgenol. 1999;172(6):1639-1641.Doi: 0.2214/ajr.172.6.10350306

2.Alexander GR, Reddi A, Reddy D. "Idiopathic Pulmonary Vein Thrombosis: A Rare Cause of Massive Hemoptysis”. Ann Thorac Surg. 2009;88(1):281-283. Doi:10.1016/j.athoracsur.2008.09.061

3. Nicola Mumoli and Marco Cei, "Idiopathic Pulmonary Vein Thrombosis," The Journal of Emergency Medicine 42, no. 2 (February 2012): 182-83, doi:10.1016/j.jemermed.2010.03.019

4. H Takeuchi, "64-MDCT Showed the Thrombus in the Pulmonary Vein of the Patient with Angina Pectoris" BMJ Case Rep. 2012;Doi: 10.1136/ bcr.02.2012.5839

5. Wu JP, Wu Q, Yang Y, DU ZZ, Sun HF. “Idiopathic Pulmonary Vein Thrombosis Extending to Left Atrium: A Case Report with a Literature Review".Chin Med J (Engl).2012;125(6):1197-1200

6. Hidekazu Takeuchi, "Floating Thrombus in the Left Upper Pulmonary Vein Dissolved by Dabigatran," BMJ Case Reports. 2013: Doi: 10.1136/ bcr-2013-200836

7. Hidekazu Takeuchi, “64-MDCT Can Depict the Thrombi Expanded from the Left Lower Pulmonary Vein to the Left Atrium in the Patient with Angina Pectoris," BMJ Case Reports. 2013; Doi: 10.1136/bcr-2013008750

8. Hidekazu Takeuchi, "Chest Pain Caused by Pulmonary Vein Thrombi Could Be Curable by Dabigatran," BMJ Case Reports. 2014. Doi: 10.1136/bcr-2013-203186

9. Hidekazu Takeuchi. "A Pulmonary Vein Thrombus in a Patient with Autonomic Nervous Dysfunction," IJC Heart \& Vasculature. 2015;8:3740. Doi:10.1016/j.ijcha.2015.05.001
10.Muhammad Asim Rana, Nicholas Tilbury, Yashwant Kumar, Habib Ahmad, Kamal Naser, Ahmed Mady, et al., "Idiopathic Pulmonary Vein Thrombus Extending into Left Atrium: A Case Report and Review of the Literature," Case Reports in Medicine. 2016:1-3. Doi:10.1155/2016/3528393

11.S D Selvidge and M LGavant, "Idiopathic Pulmonary Vein Thrombosis: Detection by CT and MR Imaging."AJR Am J Roentgenol. 1999:16391641.Doi: 10.2214/ajr.172.6.10350306

12.Gerard R Alexander, AnuReddi and Darshan Reddy. "Idiopathic Pulmonary Vein Thrombosis: A Rare Cause of Massive Hemoptysis" The Annals of Thoracic Surgery. 2009;88(1):281-83. Doi:10.1016/j. athoracsur.2008.09.061

13.Nicola Mumoli and Marco Cei. "Idiopathic Pulmonary Vein Thrombosis." The Journal of Emergency Medicine. 2012;42(2):182-83. Doi:10.1016/j.jemermed.2010.03.019

14.H Takeuchi "64-MDCT Showed the Thrombus in the Pulmonary Vein of the Patient with Angina Pectoris" BMJ Case Reports. 2012. Doi:10.1136/bcr.02.2012.5839

15.Hidekazu Takeuchi, "Floating Thrombus in the Left Upper Pulmonary Vein Dissolved by Dabigatran," BMJ Case Reports. 2013;Doi: 10.1136/ bcr-2013-200836

16.Hidekazu Takeuchi “64-MDCT Can Depict the Thrombi Expanded from the Left Lower Pulmonary Vein to the Left Atrium in the Patient with Angina Pectoris," BMJ Case Reports. 2013. Doi:10.1136/bcr-2013008750

17.Hidekazu Takeuchi "Chest Pain Caused by Pulmonary Vein Thrombi Could Be Curable by Dabigatran" BMJ Case Reports. 2014. Doi: 10.1136/bcr-2013-203186 